Розділ І. Ціннісні орієнтири духовно-інтелектуального виховання, розвиток духовно-інтелектуальних якостей особистості в умовах співпраці й інклюзії

\title{
ФЕНОМЕН НОВОЇ ЛЮДИНИ В УМОВАХ ПОГЛИБЛЕННЯ ПРИМЕНШЕННЯ ДУХОВНОСТІ В ЖИТТІ СУСПІЛЬСТВА
}

\author{
Трусей Л. Г. \\ співробітник науково-методичної лабораторії духовно-інтелектуального \\ виховання та навчання, Харківський національний педагогічний \\ університет імені Г. С. Сковороди, м. Харків, Україна
}

У статті пропонується концеепція «нової людини», засади якої простежуються в історії філософської думки та потребує нового осмислення на тлі трансформаційних процесів сучасного суспільства. Враховується історичний досвід людства з формулювання поняття людини, а також зміни соияіального довкілля людини в світі, щзо постійно змінюється. За Вернадським, людина не відокремлена істота, вона є частиною природи, космосу $і$ впливає на них, на все, щчо його оточує, отримуючи при цзьому заслужену реакцію у відповідь. У cmamті виділяються та розглядаються три основні елементи, щуо становлять нову людину: прагнення до постійного розвитку; пасіонарність та прагнення до максимальної самореалізації.

Ключові слова: нова людина, розвиток, духовність, свідомість, пасіонарність, самовдосконалення, самореалізація.

The article proposes the concept of «new man», the principles of which can be traced in the history of philosophical thought and requires a new understanding against the background of the transformational processes of modern society. According to Vernadsky, man is not a separate being, he is part of Nature, the Cosmos and affects them, everything around him, while receiving a well-deserved response. The article identifies and considers the three main elements that make up a new person: desire for continuous development; passion and desire for maximum self-realization.

Key words: new person, development, spirituality, consciousness, passionarity, self-improvement, self-realization.

Неспроможність людства своєчасно вирішити питання безпечного виходу з антропологічної кризи вимагає появи «нової людини», здатної вирішувати сучасні проблеми. Вона не може 3'явитися сама собою. Для їі появи повинні скластися відповідні умови в науці, в державному управлінні та в системі освіти. Тому розробка цієї проблеми є в край актуальною. 
У дослідженні використовуються методи філософії, зокрема вчення про категорії: одиничне, особливе, загальне, а також системні методи.

Сучасна антропологічна криза є великий розрив у розвитку людства, він досяг критичної точки, коли глибока трансформація людини неминуча. В умовах матеріальної цивілізації величезна роль належить економіці, фінансам та комерції. Вони створюють основу матеріального добробуту та призводять до соціального розшарування, що зумовлює дегенеративні стани та духовне убожество людей. Проблема в тому, що вихід з кризи потребує за короткий строк змінити людину (сучасна людина апріорі не спроможна вивести людство з кризи), тобто повинна появитись «нова» людина.

Виклики сучасного світу потребують нової концепції осмислення людини та їі готовності своєчасно реагувати на них.

1. Сучасність характеризується прискоренням та ускладненням соціокультурної динаміки, тобто змінилися соціальні частоти змін теорій, ідей, ідеологій, поглядів, технологій. Сьогодні за життя одного покоління відбуваються багаторазові зміни в навколишньому світі. Це посилюється постійно зростаючим об'ємом різнорідної інформації, котра впливає на кожну людину.

2. Протиріччя між потребами суспільства і неможливістю людини задовольнити їх, вимагає здійснення логічного аналізу до їі вирішення. Наразі нові виклики акцентують увагу на принципово нових рішеннях проблем людини, їі поведінки та ціннісно-смислових орієнтацій у сучасному світі.

3. Соціальна напруженість тривалий час призводить до роз'єднаності, замкнутості людей у собі, самотності, ослаблення соціальних зв'язків. У результаті руйнування традиційних підвалин і цінностей життя, соціального розшарування суспільства, розчарування в реформах, відсутності довіри до владних інститутів, відбувається певна деформація ставлення до законності, правосуддя. В результаті в складному соціумі виникає глибока криза системи моралі та моральності, яка тривалий час скріплювала всі суспільні підсистеми. В цих умовах соціальна реальність сприймається як простір невизначеностей і ризиків [1].

4. Небезпека світової та локальних воєн. Хантінгтон застерігає, що: “...зіткнення цивілізацій є найбільшою загрозою миру в усьому 
Розділ І. Ціннісні орієнтири духовно-інтелектуального виховання, розвиток духовно-інтелектуальних якостей особистості в умовах співпраці й інклюзії

світі, і міжнародний порядок, заснований на цивілізаціях, є найнадійнішим засобом попередження світової війни".

Однозначного, загальноприйнятого у науці визначення (поняття) людини не існує. Так, М. Шелер писав: «у жодну з епох погляди на сутність і походження людини не були настільки ненадійними, невизначеними, різноманітними, як і нашу епоху» [4]. Одним із перших відкриває новий погляд на людину як мікрокосм Микола Кузанський: «У людяності людським чином, як у Всесвіті універсальним чином, розгорнуто все, раз вона є людський світ» [2].

Микола Кузанський розглядає три складові людини: «Як відомо, людина складається з почуття, інтелекту та посередника-розуму». 3. Фрейд ясно висловлює свою ідею людини: «...людина живе прагненням до самовдосконалення, яке призвело його до сучасної висоти духовних досягнень і етичної сублімованості, і від якого можна очікувати, що воно забезпечить розвиток людини до надлюдини». Д. Салас Сомер: «Сутність кожної людини священна, тому що несе в собі Божественну іскру, еманацію Творця». Бабич В. П.: «Кожну людину природа наділила унікальною здатністю відчувати і мислити. Для цього він має Душу і Розум» [3].

У разі невизначеності ми скористаємося прийомом, коли особливості (характеристики) розглядаються у першому наближенні по перечисленню, і розглянемо деякі характеристики людини, на наш погляд, які дозволять нам підійти до розуміння нової людини та ії ролі у перебудові суспільства. Особливістю цих показників $є$ те, що вони узагальнені, тобто поєднують у собі простіші. Тут людина постає як загальне, складні характеристики - як особливе, прості характеристики - як одиничне. Порівнюючи ці характеристики, а також, які взаємодії між ними існують, ми наблизимося до розуміння феномена нової людини.

1. Призначенням людини є його прагнення безперервного розвитку, тобто формуванню необхідних якостей, починаючи з світорозуміння, розуміння сенсу життя, що закріплюються на все життя. Основними складовими є: насамперед духовне зростання, свідомість, інтелект, освіта, освоєння нових наукових знань, постійна практична діяльність. Кожному новому поколінню доводиться оновлювати знання попереднього покоління.

Люди змушені самостійно освоювати нові знання, удосконалювати свої професійні навички. Це передбачає швидке переосмислення 
досвіду як особистого, так і історичного. Досвід Тейяра як вченого пов'язаний з його розумінням глобальної важливості організації науки та іiі потенційної ролі як «не побічного заняття, а суттєвої форми діяльності». Тому система освіти зі шкільної лави повинна прищеплювати любов до самопізнання та самовдосконалення. Одна із знаменитих цитат I. Канта говорить: «Діти повинні виховуватися не для сьогодення, а для майбутнього, можливо кращого стану людського роду». У результаті - безперервне зростання масштабу особистості. М. Шелер писав: «...основний напрямок цього багатого подіями розвитку не викликає жодних сумнівів - це напрямок зростання людської самосвідомості». «Усі фундаментальні та по-справжньому прогресивні процеси - це результат розвитку знання, солідарності, кооперації та любові, а не ненависті...», — Елвін Тоффлер. Найбільш повно про значення освіти висловився Гегель: «Освіта і вивільнення з безпосередності субстанціального життя завжди і необхідно починається 3 набуття знання загальних принципів і точок зору, щоб спочатку тільки дійти думки про сутність справи взагалі, а також для того, щоб підкріпити його доказами або спростувати, осягнути конкретну та багату повноту за визначенностями та вміти прийняти щодо його належне рішення та скласти серйозне судження». На наш погляд, ієрархічно важливішим є прагнення безперервного розвитку гуманістичної сторони людини. Це насамперед духовність.

Духовність. У філософській науці ми зустрічаємо багато визначень духовності. Видатний чилійський філософ, письменник і дослідник, великий гуманіст сучасності Даріо Салас Соммер виступає за необхідність перебудови світу на основі загальнолюдської моралі та науково доводить вигоду морального способу життя.

Кримський С. підкреслює, що «духовність — це здатність переводити універсум зовнішнього буття у внутрішній світ особистості на етичній основі, здатність створювати той внутрішній світ, завдяки якому реалізується самототожність людини, iї свободи». Мартін Бубер зауважував: «Духовність є почуття зв’язку зі світом». Нам ближчими визначеннями духовності є такі: «духовність - визначена провідна... властивість, якість особистості і система певних цінностей, властивостей функціонального характеру» [4]; духовність - формулювання передових принципів і цінностей, їх освоєння, прийняття та дотримання у повсякденному житті (як динамічний процес) [5]. 
Розділ І. Ціннісні орієнтири духовно-інтелектуального виховання, розвиток духовно-інтелектуальних якостей особистості в умовах співпраці й інклюзії

По I. Канту роль і значення моралі спрямовані на внутрішній стан людини: «Мораль — $є$ вчення не про те, як ми повинні зробити себе щасливими, а про те, як ми повинні стати гідними щастя».

Носієм духовності є Свідомість. Свідомість - складне системне утворення, воно постає як здатність відображати навколишню дійсність, як універсальну здатність людини набувати знання, перетворювати, зберігати і відтворювати їх, знову забезпечувати регуляцію і ціннісні орієнтації людей, спілкуватися, обмінюватися досвідом та передавати його від одного покоління до іншого. Даріо Салас Соммер відзначав, що «бути моральним вигідно і єдине, що робить людину людиною, - це високий рівень ії свідомості». Свідомість розвивається через знання та почуття, як здатність людини виділяти себе з навколишнього світу у єдності з ним, ставитись до нього «зі знанням». Пробудження свідомості залежить від освіти, але вона не відповідає сучасним вимогам [6].

Головними завданнями освіти повинні стати: повернути освіті виховну функцію; змінити фактологічний принцип навчання на методологічний; ввести моральний стандарт, як ведучу частину освітнього стандарту на всіх рівнях; перенести акценти освітнього процесу на цілеспрямоване формування особистості для чого ввести відповідні навчальні дисципліни/предмети; інш. Удосконалення освіти одне 3 найголовніших завдань сучасності.

2. Пасіонарність. Служіння суспільству, високим ідеалам та цінностям. Найбільш широко поняття пасіонарності розкрив Л. М. Гумільов: «Пасіонарність — це непереборне внутрішнє прагнення діяльності, спрямованої на зміну свого життя, оточуючої обстановки».

Пасіонарна особистість проявляє себе у своїх діях та їх результатах, які хвилюють оточуючих індивідів — всіх інших стосуються, всім іншим близькі та зрозумілі, тобто загальні результати. Платон чи Евклід, Ньютон чи Спіноза, Бетховен чи Наполеон, Робесп'єр чи Мікеланджело, Сковорода чи Вернадський — це особи, які не викликають сумніву. В них сконцентровано соціально значуща (значуща для багатьох) справа їхнього життя, що ламає звичні застарілі, з якими інші люди змирилися, шаблони, хоча вони стали тісні для дозріваючих більш ефективних форм відносин між людьми.

Тому справжня пасіонарність, що стверджує себе з усією властивою їй енергією та волею, стає можливою лише там, де назріла по- 
треба старі стереотипи життя ламати, лише там, де закінчується період застою, панування старих штампів, і настає час революційної творчості, лише там, де виникають і стверджують себе нові форми відносин людини до самої себе та між людьми.

Масштаб пасіонарності як і особистості людини вимірюється лише масштабом тих реальних завдань, у ході вирішення яких і проявляється, і оформляється, і розгортається у справах, що хвилюють і цікавлять не тільки власну персону, а й багатьох інших людей. Чим ширше коло цих людей, тим значніша особистість. Тому сила особистості - це завжди індивідуально виражена сила того соціуму, того колективу індивідів, сила індивідуалізованої загальності устремлінь, потреб, цілей, що спрямовують їі.

Неповторність справжньої особистості полягає саме в тому, що вона по-своєму відкриває щось нове для всіх, краще за інших і повніше за інших, висловлюючи «сутність» всіх інших людей, своїми справами розсуваючи рамки можливостей, відкриваючи для всіх те, чого вони ще не знають, не вміють, не розуміють.

До необхідності пасіонарності людина приходить не відразу, а в міру духовного зростання, в основному після вирішення проблем, що кричать, вибудовування міцного фундаменту. Коли свої основні проблеми вирішені, своє життя більш-менш налагоджене, у людини з'являється природне бажання допомогти найближчому оточенню також покращити життя, проявляти милосердя до тих, хто потребує моральної підтримки, матеріальної допомоги. Спочатку одноразово, потім це стає регулярним, доброю традицією. Так серед бізнесменів (і не тільки) здавна існують традиції благодійності та меценатства (частину своїх доходів віддавати на добрі справи), брати на піклування дитячі будинки, самодіяльні творчі колективи, будинки для людей похилого віку, т. п., засновувати стипендії, ін.

3. Прагнення максимальної самореалізації у найширшому сенсі: у сім'ї, передачі родового досвіду (із покоління до покоління у суспільстві йде оновлення інформації на генетичному рівні, тобто, життя людей процес безперервного оновлення інформаційного стану суспільства); у колективі, на роботі, у творчості, з друзями; у кар'єрному зростанні, при якому зростають можливості та вплив на суспільство; в освоєнні широкого спектра діяльності - поліфункціональності - всупереч думці, що характерною рисою нашої епохи є поглиблення спеціалізації. 
Розділ І. Ціннісні орієнтири духовно-інтелектуального виховання, розвиток духовно-інтелектуальних якостей особистості в умовах співпраці й інклюзії

Людські потреби та здібності в суспільстві реалізуються в діяльності як способі буття, що інтегрує знання, уміння та цілі людини.

Зрозуміло, що ці характеристики людини не охоплюють весь спектр iii якостей, але вони задають основні напрямки формування нової людини. При цьому ми маємо на меті перебудову суспільства, виведення його із системної кризи, в якій виявилося людство, і розглянутий перелік характеристик цілком дозволяє розуміти в цьому роль нової людини.

Всеохоплюючі проекти розвитку суспільства повинні передбачати насамперед орієнтири духовного порядку [7]. Якщо програмні плани перебудови суспільства формулюються у моральних поняттях, це відкриває можливості духовного розвитку людей, прояв творчості людини. Необхідно піднести мораль до рівня загальної програми життя, зробити iii предметом розвитку людини. Дуже важливим $є$ положення про те, що свобода вибору при прийнятті рішення передбачає і морально-юридичну відповідальність за свої вчинки. Еволюція безперервного розвитку людини допоможе наповнити добром кожну думку та вчинок людини, що дозволить досягти мети, заради якої ми всі були створені, - самовдосконалення. Тільки так ми зможемо покращити світ, у якому живемо.

\section{Список використаних джерел:}

1. Дольска О. А., Голозубов А. В., Городиська О. Н.. Людина в сучасному світі: на шляху до нової парадигми освіти : монографія. Харків : Вид. центр НТУ «ХПІ», 2016.

2. Кузанский Микола. Про вчене незнання : пер. $з$ нім. Вл. Бібіхіна. Академічний проект, 2015. 160 с.

3. Бабич В. П., Могилко В. А., Онєгіна В. М. Прикладна онтологія. Харків : Мадрид, 2013.

4. Міщенко В. І. Осягнення духовності. Вісник Харківського національного університету імені В. Н. Каразіна. Серія «Філософія. Філософські перипетіï». 2017. № 56. URL https://doi.org/10.26565/2226-0994-2017-56-13.

5. Трусей Л. Г. Духовність як процес. Новітні технології - для захисту повітряного простору : тези доповідей XVI Міжнародної наукової конференції Харківського національного університету Повітряних Сил імені Івана Кожедуба. (м. Харків 15-16 квітня 2020 р.). Харків, 2020

6. Хвостиченко А. Н., Трусей Л. Г., Сердюк А. Д. Проект Концепції системи освіти «ДИВО-21». Духовно-інтелектуальне виховання і навчання молоді в XXI столітті : міжнародний збірник статей / за заг. ред. проф. В. П. Бабича, проф. Л. С. Рибалко. Харків : Вид. ВННОТ, 2019. 470 с. ISSN 2708-4809.

7. Малюта О. М. Гіперкомплексні динамічні системи. Львів : Вища школа при Львівському держ. університеті, 1989. 